\title{
Analysis of research on developmentally supportive care for prematurity in neonatal intensive care unit: a scoping review
}

\author{
Hanna Lee ${ }^{1}$, Ji Hyeon Park ${ }^{2}$, Haeryun Cho ${ }^{3}$ \\ ${ }^{1}$ Doctoral Candidate, Department of Nursing, Wonkwang University, Iksan · Charge Nurse, Department of Nursing, Wonkwang University Hospital, Iksan; \\ ${ }^{2}$ Graduate Student, Department of Nursing, Wonkwang University, Iksan; ${ }^{3}$ Associate Professor, Department of Nursing, Wonkwang University, Iksan, Korea
}

Purpose: The purpose of this study was to identify the gaps in research related to developmentally supportive care in the neonatal intensive care unit (NICU). The ultimate goal was to explore directions of further research on developmentally supportive care for premature patients. Methods: The Arksey and O'Malley scoping review method was used. Articles on developmentally supportive care for preterm infants in the NICU, written in English or Korean, were identified through electronic search engines. A total of 279 papers were identified in the initial search, of which 22 full-text papers were included in this review. Results: Several nursing studies have been published in the past 5 years. The important elements of developmentally supportive care were family-centered care and management of the NICU environment. The primary developmentally supportive care interventions were training programs to promote the care competency of NICU nurses. Conclusion: It is necessary to actively develop comprehensive developmental support interventions that consider the various elements of developmentally supportive care for preterm infants. Additional studies should be done to develop programs that provide direct intervention for premature infant and their families.

Key words: Infant, premature; Intensive care units, neonatal; Growth and development; Review

\section{Corresponding author \\ Haeryun Cho}

Department of Nursing, Wonkwang

University, 460 Iksn-daero, Iksan 54538,

Korea

TEL: +82-63-850-6020

FAX: +82-63-850-6060

E-MAIL: chr@wku.ac.kr

Received Oct 6, 2021

Revised Dec 3, 2021

Accepted Dec 22, 2021

\section{INTRODUCTION}

Globally, the likelihood of survival for premature infants is increasing due to advances in science and technology that impact the treatment and nursing care of premature infants [1-3]. The task of premature care has also been expanded to ensure optimal growth and development as well as the survival of premature newborns [4]. For the optimal growth and development of premature babies, developmentally supportive care is an intervention that manages the neonatal intensive care unit (NICU) environment so that it is as much like the intrauterine environment as possible, and provides individual and integrated interventions with the help of health professionals and the premature babies' families [5].

Scholars began to define the core concepts of developmentally supportive care for prematurity in the NICU in the late 2000s. Coughlin et al.[6] suggested five core measures, including protected sleep, stress and pain management, developmental activities of daily living, a healing environment, and family-centered care (FCC). Altimier and Phillips [1] identified seven core measures in a neonatal integrative developmental care model based on FCC: maintaining a healing environment, building a partnership with the family, safeguarding sleep, positioning and handling, protecting skin, minimizing stress/pain, and optimizing nutrition. In addition, Griffiths et al.[7] recommended nine guidelines including minimizing infant-parent separation, protecting sleep, feeding, providing skin-to-skin care, providing pain and stress management, fostering caregiving interactions, positioning, continuity in caregiving, and staff education and training. Several previous studies also dealt with the various elements of developmentally supportive care for premature infants $[3,4,8]$. Therefore, it was necessary to summarize and synthesize the existing studies on developmentally supportive care 
for premature infants in the NICU in order to identify the research gaps among those existing papers.

The Newborn Individualized Developmental Care and Assessment Program (NIDCAP), which is used worldwide in structured developmental care programs, supports the balance of the physiologic, motor, and state systems of premature infants and provides a developmentally supportive environment for premature infants and their families [9,10]. Philips Wee Care is a training program based on the neonatal integrative developmental care model by Altimier and Phillips [1]. This program aims to manage the NICU environment and the care of preterm babies [11]. These developmentally supportive care programs have a positive effect on neurodevelopment and physical growth in premature infants $[7,12,13]$, as well as reducing complication rates and shortening hospital stays [12,14]. Furthermore, developmentally supportive care in the NICU promotes parent-child attachment and reduces parental stress levels [15].

Previous studies have analyzed concepts related to developmental support, developed guidelines for developmentally supportive care [1,5-7], or covered the systematically established developmentally supportive care programs such as NIDCAP and Wee Care $[10,11,14]$. Although some studies did not deal with integrative development, they did report on specific interventions based on developmentally supportive care $[8,15,16]$. Although 40 years have passed since developmentally supportive care was first introduced in the 1980s, it remains an unfamiliar and new concept in many NICUs [17-19]. Some studies have analyzed the perceptions of NICU staff regarding developmentally supportive care [17-20], while others developed training programs and tested their effectiveness [3,4]. With the increasing interest in developmentally supportive care for preterm infants, it is necessary to comprehensively identify studies conducted in various settings that investigated nurses' perceptions and experience levels in developmentally supportive care in order to prepare basic data for practical nursing care.

A scoping review is a research method used to obtain an overview of information from a broad field rather than a detailed examination of a specific question such as in a systematic review [21]. Therefore, the purpose of this study was to identify the gaps in research related to developmentally supportive care in the NICU through a scoping review. The specific purpose was to: 1) identify the general characteristics of research related to developmentally supportive care for premature infants in the NICU; 2) identify the element gaps in developmentally supportive care in the reviewed studies; and 3 ) identify the intervention gaps related to developmentally supportive care in the reviewed studies. The ultimate goal of this study was to explore directions of further research on de- velopmentally supportive care for premature infants in the NICU.

\section{METHODS}

Ethics statement: This study was a literature review of previously published studies and was therefore exempt from institutional review board approval.

\section{Study Design}

This study was a literature review using the scoping review method presented by Arksey and O'Malley [22]. A total of 22 articles, published in academic journals from 2009 to 2020, were analyzed. The reporting of this study was based on the Preferred Reporting Items for Systematic Reviews and MetaAnalyses extension for Scoping Reviews (PRISMA-ScR) checklist [23].

\section{Study Process}

\section{1) Identifying the research question}

The first step in a scoping review is to establish the research question. Research questions are set up to establish a strategy for the literature search; therefore, research questions are set broadly to cover a wide range of research areas [22]. According to the guide of Peters et al.[24], research questions consist of population, concept, and context (PCC). The PCC of this study was: 1) population: NICU staff and preterm infants, 2 ) concept: developmentally supportive care for premature infants, and 3) context: NICU and research. Based on these criteria, the research question of this study was "What is known about the developmentally supportive care provided by staff to premature infants in the NICU as reported in published research?".

\section{2) Identifying relevant studies}

The studies analyzed in the scoping review should be included as comprehensively as possible [22]. Seo and Kim [21] suggested using a limited database for the scoping review rather than a systematic literature review. Therefore, the electronic databases of this study included PubMed, CINAHL, and Web of Science. The main keywords were combinations of "premature", "infant", "prematurity", "preterm infant", "developmentally supportive care", "developmental support care", "integrative developmental care", "nurses," and "staff". The search strategies for each database are shown in Supplement 1. The search queries for each database were reviewed by a medical librarian. The publication period was set from 2009 
to 2020 , based on the years when the core measures for developmentally supportive care in the NICU [6] and the conceptual framework for several studies related to developmentally supportive care were published.

As a result of a search on January 16, 2021, a total of 279 articles were identified, including 231 in PubMed, 10 in CINAHL, and 38 in Web of Science. The titles of the searched papers were entered into the Excel program to check for duplicate papers and 31 duplicates were removed. The subject for review was identified in 248 articles, and the titles and abstracts of all papers were obtained (Figure 1).

\section{3) Selection of studies for inclusion}

Research was excluded that was not related to the research question. To broadly examine the relevant areas, scoping review does not conduct rigorous paper quality evaluations [22]. The inclusion criteria for this study were: 1) research articles in academic journals dealing with developmentally supportive care for preterm infants, 2) peer-reviewed research, 3) research published in English or Korean languages, and 4) research published from 2009 to 2020 . The exclusion criteria were: 1) editorials or letters to editors, 2) conference proceedings, 3) research on specific diseases, 4) research including NICU graduates or follow-ups, and 5) research simply evaluating NIDCAP.

To minimize the risk of selection bias, the researchers in- dependently reviewed each step of the process and met to discuss their opinions. In the first step, the titles and abstracts of 248 papers were reviewed and 227 were excluded. In the second step, the full text of 21 papers was secured and reviewed. No papers were excluded, and 3 papers from the reference lists were added for analysis. In the third step, selected papers were re-reviewed for recording data. The study design, subjects, variables, and findings were selected as rough data, followed by a pilot analysis. The inclusion and exclusion criteria for the 24 papers were carefully reviewed. One paper on developmentally supportive care after discharge from the NICU and another study on simple evaluation of NIDCAP were excluded. Finally, 22 papers were selected as the study targets for analysis (Figure 1).

\section{4) Charting the data}

Each of the three researchers independently analyzed the 22 papers for the following items: the first author, year of publication, academic field, nation in which the research was conducted, study design, subjects, sample size, study aim, main variables, key findings, and elements of developmentally supportive care. The recording chart referred to the data chart form of a previous scoping review [24], and data were recorded using the Excel program according to the guidelines of Arksey and O'Malley [22]. After exchanging and reviewing

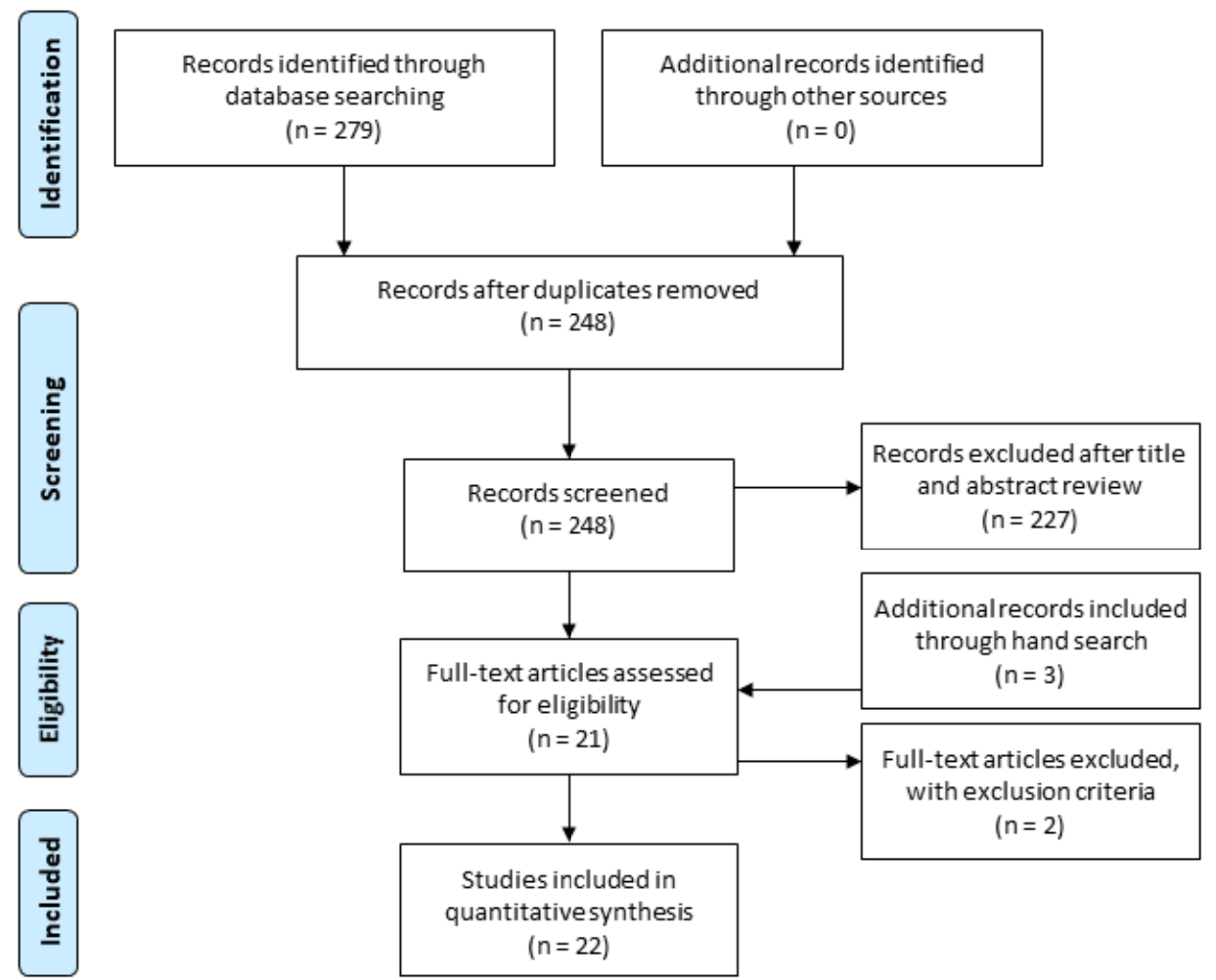

Figure 1. Flow diagram for study selection. 
each recorded chart, regular research meetings were held and a matrix was completed by exchanging opinions on each record (Table 1) [1,3-8,15-20,25-33].

\section{5) Collating, summarizing, and reporting results}

The researchers analyzed and summarized the results of the study according to the guidelines for scoping review [22]. In line with the purpose of this study, the tables were prepared so that the results of the study could be summarized. The general characteristics of the studies on developmentally supportive care, including academic field, nation in which the studies were conducted, study designs, and subjects were summarized using frequency and percentage. The analyzed data were summarized by the characteristics of the papers written before 2010, between 2011 and 2015, and between 2016 and 2020. To identify the elements of developmentally supportive care, the elements covered in the reviewed paper were tabulated. Finally, to identify intervention gaps in developmentally supportive care, the data on the characteristics of developmentally supportive care interventions for premature infants were summarized.

\section{6) Consultation exercise}

The last step was optional, to validate the results analyzed in this study. The researchers submitted written reports on the study question, study purpose, and preliminary results to three child nursing professors and two nurses with more than 10 years of experience in the NICU. These experts reviewed the results of this study and decided that the results were valid for the research question and purpose of the study. Therefore, with the validity secured, the preliminary results of this study were confirmed as the final results, without modification.

\section{RESULTS}

\section{General Characteristics of the Selected Studies}

The collected studies [1,3-8,15-20,25-33] included one study before 2010, three from 2011 to 2015, and 18 from 2016 to 2020. The studies were conducted in nursing $(68.2 \%)$ and medicine (31.8\%). Four (18.5\%) were from South Korea; the USA, Egypt, and India had three each (13.6\%); Iran and Australia had two each (9.1\%); and Canada, China, South Africa, Lebanon, and Germany had one each $(4.5 \%)$. The literature review, experimental study, and descriptive study designs consisted of six articles $(27.3 \%)$ each. The concept analysis design and qualitative study design included one article (4.5\%) each, and the methodology study design consisted of two articles (9.1\%). Of the 15 papers, excluding literature reviews and concept analyses, the study of NICU nurses was the most common $(n=11$ papers, $73.3 \%$ ) (Table 2).

\section{Elements of Developmentally Supportive Care for Pre- term Infants}

Among the analyzed papers, 13 studies [1,3-8,25-27,29,31,32] dealt with the elements of developmentally supportive care. Table 3 presents the elements of developmentally supportive care $[1,3-8,25-27,29,31,32]$. The most common elements were FCC $(84.6 \%)[1,3-8,26,27,29,32]$, and a healing environment $(84.6 \%)$ $[1,3-8,25-27,32]$, followed by positioning $(76.9 \%)[1,3,4,6-8,25$, $26,29,32]$, oral feeding support $(61.5 \%)$ [1,3,4,6,7,25,29,32], pain and stress management (61.5\%) [1,4,6-8,27,31,32], and protected sleep $(53.8 \%)$ [1,4,6-8,27,32]. In addition, overlap was seen with handling (38.5\%) $[1,4,7,26,32]$, skin care $(30.8 \%)[1,4,6,8]$, and sensory stimulation $(15.4 \%)$ [25,32].

\section{Characteristics of Interventions Related to Develop- mentally Supportive Care for Preterm Infants}

Among the analyzed papers, 6 studies [3,4,16,17,25,29] dealt with interventions in the developmentally supportive care of the preterm infant. Analysis of the characteristics of these interventions showed that three studies were based on theoretical frameworks. The three applied frameworks were a developmental clinical care guideline [3], a synactive theory of infant development [17], and a neonatal integrative developmental care model [4]. In four papers, the subjects of intervention were NICU doctors and nurses $[3,4,17,25]$, and in two papers the subjects were preterm infants and parents [16,29]. Intervention periods were from 1 week to 4 weeks, and sessions varied from two to seven sessions. For outcome measurements when the NICU staff was the target, knowledge and behavior checklists, and interviews were measured. When preterm infants and parents were targeted, pain, stress, development, and motor scales were measured (Table 4) $[3,4,16,17,25$, 29].

\section{DISCUSSION}

This study was conducted to understand the research gap in developmentally supportive care for premature infants in the NICU using the scoping review. The general characteristics of the reviewed studies, the elements of developmentally supportive care, and the characteristics of developmentally supportive care interventions for prematurity were analyzed.

The general characteristics of the reviewed research showed that several studies had been published in the past five years. Active treatment interventions for preterm infants had become possible due to the development of medical technology 
Table 1. Summary of the Reviewed Research $(N=22)$

\begin{tabular}{|c|c|c|c|c|c|c|}
\hline $\begin{array}{l}\text { 1st author } \\
\text { (year) }[R]\end{array}$ & $\begin{array}{l}\text { Academic } \\
\text { field }\end{array}$ & $\begin{array}{l}\text { Research } \\
\text { nation }\end{array}$ & $\begin{array}{l}\text { Study } \\
\text { design }\end{array}$ & $\begin{array}{c}\text { Subject } \\
\text { (sample size) }\end{array}$ & Study aim & Key finding \\
\hline $\begin{array}{l}\text { Altimier } \\
(2016)[1]\end{array}$ & Nursing & USA & Model development & $\begin{array}{l}\text { Not } \\
\text { applicable }\end{array}$ & $\begin{array}{l}\text { To provide the neonatal } \\
\text { integrative } \\
\text { developmental care } \\
\text { model }\end{array}$ & $\begin{array}{l}\text { The seven neuroprotective core measures presented by the } \\
\text { lotus flower illustration are: healing environment, } \\
\text { partnering with infants' families, positioning and } \\
\text { handling, safeguarding sleep, minimizing stress and pain, } \\
\text { protecting skin, and optimizing nutrition. }\end{array}$ \\
\hline $\begin{array}{l}\text { Austin } \\
\text { (2019) [17] }\end{array}$ & Nursing & $\begin{array}{l}\text { South } \\
\text { Africa }\end{array}$ & Qualitative study & $\begin{array}{l}\text { NICU RNs } \\
\text { (14) }\end{array}$ & $\begin{array}{l}\text { To explore compliance } \\
\text { with DSC care prin- } \\
\text { ciples implemented in } \\
\text { a South African NICU. }\end{array}$ & $\begin{array}{l}\text { Three main themes were included value of DSC, nature of } \\
\text { DSC, and barriers to DSC. }\end{array}$ \\
\hline $\begin{array}{l}\text { Baghlani } \\
\text { (2019) [33] }\end{array}$ & Nursing & Iran & $\begin{array}{l}\text { Cross-sectional } \\
\text { study }\end{array}$ & $\begin{array}{l}\text { NICU nurses } \\
(120)\end{array}$ & $\begin{array}{l}\text { To assess nurses' } \\
\text { knowledge and } \\
\text { perception of NIDCAP }\end{array}$ & $\begin{array}{l}\text { The majority of nurses participating in the study had high } \\
\text { knowledge about NIDCAP. }\end{array}$ \\
\hline $\begin{array}{l}\text { Charafeddine } \\
(2020)[20]\end{array}$ & Medicine & Lebanon & $\begin{array}{l}\text { Cross-sectional } \\
\text { anonymous online } \\
\text { survey }\end{array}$ & $\begin{array}{l}\text { NICU staff } \\
\text { (RNs 29, } \\
\text { physicians } \\
28)\end{array}$ & $\begin{array}{l}\text { To assess the perceptions } \\
\text { and experience of } \\
\text { NICU staff during } \\
\text { NIDCAP } \\
\text { implementation }\end{array}$ & $\begin{array}{l}\text { In a low-/middle-income country, the implementation of } \\
\text { NIDCAP was perceived as a positive experience for both } \\
\text { nurses and doctors. }\end{array}$ \\
\hline $\begin{array}{l}\text { Coughlin } \\
\text { (2009) [6] }\end{array}$ & Nursing & USA & Literature review & $\begin{array}{l}\text { Papers (do not } \\
\text { report) }\end{array}$ & $\begin{array}{l}\text { To discuss core measures } \\
\text { for DSC in NICU }\end{array}$ & $\begin{array}{l}\text { Five core measure sets for evidence-based DSC were } \\
\text { evaluated: protected sleep, pain and stress assessment and } \\
\text { management, developmental activities of daily living, } \\
\text { FCC, and healing environment. }\end{array}$ \\
\hline $\begin{array}{l}\text { Esser } \\
(2018)[8]\end{array}$ & Nursing & USA & Literature review & $\begin{array}{l}\text { Not } \\
\text { applicable }\end{array}$ & $\begin{array}{l}\text { To review how DSC can } \\
\text { be optimally integrated } \\
\text { with diapering in } \\
\text { NICU }\end{array}$ & $\begin{array}{l}\text { Neurodevelopmental opportunities to expand DSC into } \\
\text { diapering care are identified; protecting and promoting } \\
\text { sleep for preterm infants, enhancing the diapering } \\
\text { environment, minimizing stress that infants may } \\
\text { experience with diapering, improving infant's skin health } \\
\text { outcomes, and fostering family involvement. }\end{array}$ \\
\hline $\begin{array}{l}\text { Fawzia } \\
\text { (2017) [16] }\end{array}$ & Nursing & Egypt & $\begin{array}{l}\text { Control group } \\
\text { pretest-posttest } \\
\text { quasi-experimental } \\
\text { study }\end{array}$ & $\begin{array}{l}\text { Preterm infant } \\
\text { (EG 28, CG } \\
28)\end{array}$ & $\begin{array}{l}\text { To evaluate the } \\
\text { effectiveness of DSP }\end{array}$ & $\begin{array}{l}\text { Premature infants with DSP had acceptable positions and } \\
\text { had lower pain scores. }\end{array}$ \\
\hline $\begin{array}{l}\text { Griffiths } \\
\text { (2019) [7] }\end{array}$ & Medicine & Australia & Literature review & $\begin{array}{l}\text { Papers } \\
\text { (do not } \\
\text { report) }\end{array}$ & $\begin{array}{l}\text { To guide practice } \\
\text { recommendations for } \\
\text { the application of DSC } \\
\text { to clinicians. }\end{array}$ & $\begin{array}{l}\text { Key components of neuroprotective DSC were as follows: } \\
\text { minimizing parent and infant separation, maintaining } \\
\text { supportive sensory environment, protecting sleep, } \\
\text { feeding, providing skin to skin care, managing pain and } \\
\text { stress, encouraging caregiving interactions, positioning, } \\
\text { supporting continuity in caregiving, and providing staff } \\
\text { training. }\end{array}$ \\
\hline $\begin{array}{l}\text { Halder } \\
(2015)[26]\end{array}$ & Medicine & India & Literature review & $\begin{array}{l}\text { Not } \\
\text { applicable }\end{array}$ & $\begin{array}{l}\text { To briefly review current } \\
\text { literature }\end{array}$ & $\begin{array}{l}\text { The practices of DSC are: anytime access of mothers to } \\
\text { babies, messages regarding infants, nesting, and proper } \\
\text { handling. } \\
\text { DSC is aimed at decreasing the stress levels in infants by } \\
\text { individualized care that also involves the infant's family. }\end{array}$ \\
\hline $\begin{array}{l}\text { Hong } \\
(2020)[19]\end{array}$ & Nursing & $\begin{array}{l}\text { South } \\
\text { Korea }\end{array}$ & Descriptive study & $\begin{array}{l}\text { NICU nurses } \\
(139)\end{array}$ & $\begin{array}{l}\text { To identify factors } \\
\text { related to DCS } \\
\text { performance among } \\
\text { NICU nurses }\end{array}$ & $\begin{array}{l}\text { More than half of the subjects responded that they had } \\
\text { never received DSC education. } \\
\text {. For } 89.6 \% \text { of those who had received DSC education, it } \\
\text { was a one-time event. } \\
\text {. Nursing work environment and DSC perceptions } \\
\text { influenced DSC performance. }\end{array}$ \\
\hline $\begin{array}{l}\text { Jannes } \\
(2020)[15]\end{array}$ & Medicine & Germany & $\begin{array}{l}\text { Prospective } \\
\text { multicenter study }\end{array}$ & $\begin{array}{l}\text { Parents } \\
(1,277)\end{array}$ & $\begin{array}{l}\text { To assess the impact of } \\
\text { organizational FCC } \\
\text { characteristics at } \\
\text { German NICUs on the } \\
\text { satisfaction of parents }\end{array}$ & $\begin{array}{l}\text { The provision of DSC and unrestricted visiting hours to } \\
\text { foster the parent-infant interaction significantly } \\
\text { contributes to the satisfaction of parents. }\end{array}$ \\
\hline $\begin{array}{l}\text { Kaye } \\
(2016) \text { [27] }\end{array}$ & Nursing & Australia & Historical trends & $\begin{array}{l}\text { Not } \\
\text { applicable }\end{array}$ & $\begin{array}{l}\text { To provide a historical } \\
\text { overview of } \\
\text { developmental care }\end{array}$ & $\begin{array}{l}\text { DSC is described as a philosophy of care that requires } \\
\text { rethinking the relationships between healthcare providers, } \\
\text { infants, and families. } \\
\text {. Various models of DSC include a variety of activities } \\
\text { designed to manage the environment and individualize } \\
\text { the care provided to preterm and high-risk infants. }\end{array}$ \\
\hline
\end{tabular}

CG, control group; DSC, developmentally supportive care; DSP, developmentally supportive positioning; EG, experimental group; FCC, family-centered care; KMC, kangaroo mother care; NBAS, neonatal behavioral assessment scale; NICU, neonatal intensive care unit; NIDCAP, newborn individualized developmental care and assessment program; [R], reference number; $R N$, registered nurse. 
Table 1. Summary of the Reviewed Research (Continued) $(N=22)$

\begin{tabular}{|c|c|c|c|c|c|c|}
\hline $\begin{array}{l}\text { 1st author } \\
\text { (year) [R] }\end{array}$ & $\begin{array}{l}\text { Academic } \\
\text { field }\end{array}$ & $\begin{array}{l}\text { Research } \\
\text { nation }\end{array}$ & $\begin{array}{l}\text { Study } \\
\text { design }\end{array}$ & $\begin{array}{c}\text { Subject } \\
\text { (sample size) }\end{array}$ & Study aim & Key finding \\
\hline $\begin{array}{l}\text { Khawash } \\
(2018)[32]\end{array}$ & Medicine & India & Literature review & $\begin{array}{l}\text { Not } \\
\text { applicable }\end{array}$ & $\begin{array}{l}\text { To identify training } \\
\text { modules of NICU staff } \\
\text { in early DCS for } \\
\text { newborns }\end{array}$ & $\begin{array}{l}\text { Neuromotor module trains NICU staff regarding the } \\
\text { importance of individualized positioning and optimal } \\
\text { handling of high-risk infants in the NICU. } \\
\text { Neurosensory module aims to train NICU staff on } \\
\text { providing sensory neuroprotective care including tactile, } \\
\text { auditory, visual, olfactory, and gustatory modalities, } \\
\text { protecting sleep, and managing pain and the healing } \\
\text { environment. } \\
\text { The module on strategies included feeding practices and } \\
\text { KMC. }\end{array}$ \\
\hline $\begin{array}{l}\text { Kim } \\
(2018)[30]\end{array}$ & Nursing & $\begin{array}{l}\text { South } \\
\text { Korea }\end{array}$ & $\begin{array}{l}\text { Cross-sectional } \\
\text { descriptive } \\
\text { correlation study }\end{array}$ & $\begin{array}{l}\text { NICU nurses } \\
\text { (131) }\end{array}$ & $\begin{array}{l}\text { To assess the knowledge } \\
\text { and performance of } \\
\text { DSP for preterm infants } \\
\text { among NICU nurses }\end{array}$ & $\begin{array}{l}\text { NICU nurses' mean score of DSP knowledge was } 24.7 \text { out } \\
\text { of } 33.0 \text {, and DSP performance was } 3.2 \text { out of } 4.0 \text {. } \\
\text { A positive correlation was found between knowledge and } \\
\text { performance of DSP. }\end{array}$ \\
\hline $\begin{array}{l}\text { Kim } \\
\quad(2016)[28]\end{array}$ & Nursing & $\begin{array}{l}\text { South } \\
\text { Korea }\end{array}$ & Scale development & $\begin{array}{l}\text { NICU nurses } \\
(122)\end{array}$ & $\begin{array}{l}\text { To develop and evaluate } \\
\text { the Developmental } \\
\text { Support Competency } \\
\text { Scale for Nurses }\end{array}$ & $\begin{array}{l}\text { The Developmental Support Competency Scale for Nurses } \\
\text { was a 4-point Likert type scale, consisting of } 19 \text { items. } \\
\text { The following six factors were derived: environmental } \\
\text { support (4 items), parental support (3), interaction (3), } \\
\text { critical thinking (3), professional development (3), and } \\
\text { partnership (3). }\end{array}$ \\
\hline
\end{tabular}

\begin{tabular}{|c|c|c|c|c|c|c|}
\hline $\begin{array}{l}\text { Kim } \\
(2014)[5]\end{array}$ & Nursing & $\begin{array}{l}\text { South } \\
\text { Korea }\end{array}$ & Concept analysis & $\begin{array}{l}\text { Papers (77), } \\
\text { NICU RNs } \\
(5)\end{array}$ & $\begin{array}{l}\text { To define and clarify the } \\
\text { concept of DSC for } \\
\text { preterm infants }\end{array}$ & $\begin{array}{l}\text { For the nursing practice, resembling the intrauterine state, } \\
\text { individualization, interaction, and integrative care with } \\
\text { awareness of development were attributes of DSC. } \\
\text {. For FCC, supporting parental attachment and professional } \\
\text { alliance were attributes of DSC. }\end{array}$ \\
\hline $\begin{array}{l}\text { Luu } \\
\text { (2017) [29] }\end{array}$ & Medicine & Canada & $\begin{array}{l}\text { Control group } \\
\text { pretest-posttest } \\
\text { quasi-experimental } \\
\text { study }\end{array}$ & $\begin{array}{l}\text { Infants (EG } \\
55, \text { CG 52) }\end{array}$ & $\begin{array}{l}\text { To test the acceptability } \\
\text { of the intervention and } \\
\text { assess infants' } \\
\text { neurodevelopmental } \\
\text { and parental outcomes }\end{array}$ & $\begin{array}{l}\text { The acceptability of the program was high among parents. } \\
\text {. No differences were found in infants' neurodevelopmental } \\
\text { and parental outcomes. }\end{array}$ \\
\hline $\begin{array}{c}\text { Mohammed } \\
\text { (2018) [3] }\end{array}$ & Nursing & Egypt & $\begin{array}{l}\text { Single-group pretest } \\
\text { and posttest } \\
\text { quasi-experimental } \\
\text { design }\end{array}$ & $\begin{array}{l}\text { NICU nurses } \\
(50)\end{array}$ & $\begin{array}{l}\text { To investigate the effect } \\
\text { of a preterm infants' } \\
\text { DCS program on NICU } \\
\text { nurses' performance }\end{array}$ & $\begin{array}{l}\text { Nurses had a good performance score on DSC } \\
\text { immediately after the intervention, and it decreased after } 3 \\
\text { months of the intervention. }\end{array}$ \\
\hline $\begin{array}{c}\text { Mohammed } \\
\text { (2014) [25] }\end{array}$ & Nursing & Egypt & $\begin{array}{l}\text { Single-group pretest } \\
\text { and posttest } \\
\text { quasi-experimental } \\
\text { design }\end{array}$ & $\begin{array}{l}\text { NICU nurses } \\
(40) \text {, } \\
\text { Newborn } \\
\text { babies (40) }\end{array}$ & $\begin{array}{l}\text { To evaluate the effect of } \\
\text { DSC training program } \\
\text { during tub bath }\end{array}$ & $\begin{array}{l}\text { The level of nurses' performance increased significantly } \\
\text { after the DSC training program. } \\
\text { The mean NBAS scores all significantly improved after the } \\
\text { training DSC program. } \\
\text { The infants exhibited less stress and greater comfort } \\
\text { during tub baths after the training DSC program. }\end{array}$ \\
\hline $\begin{array}{l}\text { Nejad } \\
(2018)[31]\end{array}$ & Medicine & Iran & $\begin{array}{l}\text { Cross-sectional } \\
\text { descriptive study }\end{array}$ & NICU (23) & $\begin{array}{l}\text { To assess the DSC } \\
\text { situation in Iranian } \\
\text { NICUs and to design } \\
\text { and provide clinical } \\
\text { DSC guidelines for } \\
\text { health care providers } \\
\text { and the infant's family }\end{array}$ & $\begin{array}{l}\text { The low mean score of infant-centered DSC implies that } \\
\text { the healthcare provider require support and training in } \\
\text { order to focus on quality DSC, and that inadequate } \\
\text { attention is given to the infant and family as active } \\
\text { members in care. }\end{array}$ \\
\hline $\begin{array}{l}\text { Sathish } \\
\text { (2019) [4] }\end{array}$ & Nursing & India & $\begin{array}{l}\text { Control group } \\
\text { pretest-posttest } \\
\text { quasi-experimental } \\
\text { study }\end{array}$ & $\begin{array}{l}\text { level III B } \\
\text { NICU } \\
\text { nurses (EG } \\
25, \text { CG 25) }\end{array}$ & $\begin{array}{l}\text { To enhance NICU } \\
\text { nurses' abilities of DSC } \\
\text { practices }\end{array}$ & $\begin{array}{l}\text { The DSC program had a significant impact on improving } \\
\text { NICU nurses' ability to prevent complications and provide } \\
\text { DSC to preterm infants. }\end{array}$ \\
\hline $\begin{array}{l}\text { Zhang } \\
\text { (2016) [18] }\end{array}$ & Nursing & China & $\begin{array}{l}\text { Descriptive, } \\
\text { cross-sectional } \\
\text { exploratory study }\end{array}$ & $\begin{array}{l}\text { NICU RNs } \\
\text { (207) }\end{array}$ & $\begin{array}{l}\text { To describe levels of } \\
\text { DSC nursing practices } \\
\text { among NICU nurses }\end{array}$ & $\begin{array}{l}\text { Chinese NICU nurses are not implementing DSC } \\
\text { consistently. } \\
\text { The significant predictors for lower implementation of DSC: } \\
\text { higher patient caseloads, fewer work hours per day, higher } \\
\text { level of education, and fewer years worked in NICUs. } \\
\text { Chinese NICU nurses carry out DSC mainly based on their } \\
\text { accumulated clinical experience rather than their } \\
\text { educational experience. }\end{array}$ \\
\hline
\end{tabular}

CG, control group; DSC, developmentally supportive care; DSP, developmentally supportive positioning; EG, experimental group; FCC, family-centered care; KMC, kangaroo mother care; NBAS, neonatal behavioral assessment scale; NICU, neonatal intensive care unit; NIDCAP, newborn individualized developmental care and assessment program; [R], reference number; RN, registered nurse. 
Table 2. General Characteristics of Reviewed Research $(N=22)$

\begin{tabular}{|c|c|c|c|c|c|}
\hline \multirow[t]{2}{*}{ Categories } & \multirow[t]{2}{*}{ Characteristics } & $\begin{array}{l}\text { Total } \\
(n=22)\end{array}$ & $\begin{array}{c}2009-2010 \\
(n=1)\end{array}$ & $\begin{array}{c}2011-2015 \\
(n=3)\end{array}$ & $\begin{array}{c}2016-2020 \\
\quad(n=18)\end{array}$ \\
\hline & & $\mathrm{n}(\%)$ & $\mathrm{n}(\%)$ & $\mathrm{n}(\%)$ & $\mathrm{n}(\%)$ \\
\hline \multirow[t]{2}{*}{ Academic field } & Nursing & $15(68.2)$ & $1(100.0)$ & $2(66.7)$ & $12(66.7)$ \\
\hline & Medicine & $7(31.8)$ & - & $1(33.3)$ & $6(33.3)$ \\
\hline \multirow{11}{*}{ Research nation } & South Korea & $4(18.5)$ & - & $1(33.3)$ & $3(16.5)$ \\
\hline & USA & $3(13.6)$ & $1(100.0)$ & - & $2(11.1)$ \\
\hline & Egypt & $3(13.6)$ & - & $1(33.3)$ & $2(11.1)$ \\
\hline & India & $3(13.6)$ & - & $1(33.3)$ & $2(11.1)$ \\
\hline & Iran & $2(9.1)$ & - & - & $2(11.1)$ \\
\hline & Australia & $2(9.1)$ & - & - & $2(11.1)$ \\
\hline & Canada & $1(4.5)$ & - & - & $1(5.6)$ \\
\hline & China & $1(4.5)$ & - & - & $1(5.6)$ \\
\hline & South Africa & $1(4.5)$ & - & - & $1(5.6)$ \\
\hline & Lebanon & $1(4.5)$ & - & - & $1(5.6)$ \\
\hline & Germany & $1(4.5)$ & - & - & $1(5.6)$ \\
\hline \multirow[t]{6}{*}{ Study design } & Literature review & $6(27.3)$ & $1(100.0)$ & $1(33.3)$ & $4(22.2)$ \\
\hline & Experimental study & $6(27.3)$ & - & $1(33.3)$ & $5(27.8)$ \\
\hline & Descriptive study & $6(27.3)$ & - & - & $6(33.3)$ \\
\hline & Concept analysis & $1(4.5)$ & - & $1(33.3)$ & - \\
\hline & Methodological study & $2(9.1)$ & - & - & $2(11.1)$ \\
\hline & Qualitative study & $1(4.5)$ & - & - & $1(5.6)$ \\
\hline \multirow{5}{*}{ Subjects* } & & $(n=15)$ & $(n=0)$ & $(n=2)$ & $(n=13)$ \\
\hline & NICU nurse & $11(73.3)$ & - & $2(100.0)$ & $9(69.2)$ \\
\hline & Infant & $3(20.0)$ & - & $1(50.0)$ & $2(15.4)$ \\
\hline & Parent & $1(6.7)$ & - & - & $1(7.7)$ \\
\hline & NICU & $1(6.7)$ & - & - & $1(7.7)$ \\
\hline
\end{tabular}

*Multiple response, including only human participant research; NICU, neonatal intensive care unit.

and, as a result, the survival rate of premature infants increased [1-3]. This finding is also considered to be the result of emerging new interests that support and promote growth and development as well as the survival of preterm infants $[1,5]$. In particular, it was confirmed that studies on developmentally supportive care were being actively conducted in the nursing field. The role of the nurses who take care of premature infants 24 hours each day in the NICU is important to the outcome of preterm infants who are hospitalized after birth and are completely entrusted to health care providers [34]. In this context, developmental support care for preterm infants is of great interest to nursing. Nursing care is aimed at overall well-being, including physical, social, mental, and spiritual well-being [17]. Development is dependent on addressing all aspects of growth, including sleep, stress, nutrition, senses, movement, and attachment [1,5-7]. Therefore, developmentally supportive care is complementary to nursing care, which also provides holistic management. Although a multidisciplinary approach is needed to support the development of premature infants [4,35], the trend of research led by nursing is meaningful.

Studies have been conducted on developmentally supportive care in various countries. To provide active interventions for the development of premature infants, NIDCAP has training centers in many countries including the USA, Canada, Europe, Israel, Argentina, and Australia [9]. We found that studies on supportive care for the development of preterm infants had been conducted in the USA $[1,6,8]$, Australia [7,27], Canada [29], and Germany [15], which are also countries implementing NIDCAP. It is worth noting that 15 of the 22 analyzed studies were conducted in South Korea $[5,19,28,30]$, Egypt [3,16,25], India [4,26,32], Iran [31,33], China [18], South Africa [17], and Lebanon [20], which are countries without a NIDCAP training center. This result suggests that developmentally supportive care is not an issue to be addressed only by specific programs such as NIDCAP or Philips Wee Care, but is now an issue that must be addressed universally in all NICUs for high-quality prematurity care.

The subjects of many of the studies were NICU nurses. Many descriptive research studies were conducted with NICU nurses to analyze the current knowledge of developmentally supportive care and to prepare the foundation necessary to develop and apply the interventions of developmentally supportive care $[18,19,30]$. As found in this study, this reflects the importance of supporting research activities on development- 
Table 3. Elements of Developmentally Supportive Care $(N=13)$

\begin{tabular}{|c|c|c|c|c|c|c|c|c|c|c|}
\hline First author $[R]$ & $\begin{array}{l}\text { Family } \\
\text {-centered } \\
\text { care }\end{array}$ & $\begin{array}{l}\text { Healing } \\
\text { environ- } \\
\text { ment }\end{array}$ & $\begin{array}{l}\text { Position- } \\
\text { ing }\end{array}$ & $\begin{array}{c}\text { Oral } \\
\text { feeding } \\
\text { support }\end{array}$ & $\begin{array}{l}\text { Pain and } \\
\text { stress } \\
\text { manage- } \\
\text { ment }\end{array}$ & $\begin{array}{l}\text { Protected } \\
\text { sleep }\end{array}$ & Handling & $\begin{array}{l}\text { Skin } \\
\text { care }\end{array}$ & $\begin{array}{l}\text { Sensory } \\
\text { stimula- } \\
\text { tion }\end{array}$ & Others \\
\hline & $\mathrm{n}(\%)$ & $\mathrm{n}(\%)$ & $\mathrm{n}(\%)$ & $\mathrm{n}(\%)$ & $\mathrm{n}(\%)$ & $\mathrm{n}(\%)$ & $\mathrm{n}(\%)$ & $\mathrm{n}(\%)$ & $\mathrm{n}(\%)$ & $\mathrm{n}(\%)$ \\
\hline & 11 (84.6) & $11(84.6)$ & $10(76.9)$ & $8(61.5)$ & $8(61.5)$ & $7(53.8)$ & $5(38.5)$ & $4(30.8)$ & $2(15.4)$ & $7(53.8)$ \\
\hline Altimier [1] & $\bullet$ & • & $\bullet$ & • & • & $\bullet$ & $\bullet$ & $\bullet$ & & \\
\hline Coughlin [6] & • & • & $\bullet$ & • & $\bullet$ & $\bullet$ & & $\bullet$ & & \\
\hline Esser [8] & $\bullet$ & $\bullet$ & $\bullet$ & & $\bullet$ & $\bullet$ & & $\bullet$ & & \\
\hline Griffiths [7] & $\bullet$ & $\bullet$ & $\bullet$ & - & $\bullet$ & • & $\bullet$ & & & $\begin{array}{l}\text { Continuity in } \\
\text { caregiving } \\
\text {-Staff education } \\
\text { and training }\end{array}$ \\
\hline Halder [26] & • & • & $\bullet$ & & & & $\bullet$ & & & - Containment \\
\hline Kaye [27] & • & - & & & • & • & & & & \\
\hline Khawash [32] & - & $\bullet$ & $\bullet$ & - & - & - & $\bullet$ & & $\bullet$ & \\
\hline Kim [5] & ○ & $\bullet$ & & & & & & & & $\begin{array}{l}\text { - Integrative care } \\
\text { with awareness of } \\
\text { development } \\
\text { - Individualization }\end{array}$ \\
\hline Luu [29] & ○ & & $\bullet$ & $\bullet$ & & & & & & $\begin{array}{l}\text { - Infant behavioral } \\
\text { cues }\end{array}$ \\
\hline Mohammed [3] & $\bullet$ & $\bullet$ & - & - & & & & & & . Containment \\
\hline Mohammed [25] & & • & $\bullet$ & $\bullet$ & & & & & • & \\
\hline Nejad [31] & & & & & • & & & & & $\begin{array}{l}\text {-Supporting the } \\
\text { infants' state } \\
\text { organization } \\
\text { - Documentation } \\
\text { for DSC } \\
\text { - NICU staffing for } \\
\text { DSC }\end{array}$ \\
\hline Sathish [4] & $\bullet$ & $\bullet$ & $\bullet$ & $\bullet$ & $\bullet$ & $\bullet$ & $\bullet$ & - & & $\begin{array}{l}\text { - Understanding } \\
\text { preterm } \\
\text { behavioral } \\
\text { development }\end{array}$ \\
\hline
\end{tabular}

DSC, developmentally supportive care; NICU, neonatal intensive care unit; [R], reference number.

ally supportive care, even in countries where programs such as NIDCAP have not been introduced. NIDCAP not only includes training programs to train health care providers, but also aims to establish a model NICU system to promote the proper development of premature infants $[9,20]$. Further studies are necessary to expand the number of study subjects to include the whole NICU system, premature babies, and their families in order to provide high-quality developmentally supportive care for premature babies.

The elements of developmentally supportive care most frequently identified were FCC and environmental management. The FCC that was most frequently addressed in the reviewed studies can be attributed to the findings of Chung et al.[36], which reported that the NICU staff recognizes FCC as an important part of clinical practice and is not just theoretical. Jannes et al.[15] reported that a family-centered developmentally supportive care program had a significant effect on the satisfaction of parents of preterm infants. Family-centered developmentally supportive care includes both health professionals and families as the developmentally supportive care providers for premature infants. Families are trained to participate in care in partnership with healthcare professionals [36]. Zhang et al.[18] analyzed the perception of developmentally supportive care among Chinese NICU nurses and reported that the NICU nurses evaluated themselves as unable to provide family-centered developmentally supportive care during 
Table 4. Characteristics of Developmentally Supportive Care Interventions $(N=6)$

\begin{tabular}{|c|c|c|c|c|c|c|c|c|c|}
\hline $\begin{array}{l}\text { First author } \\
\text { [R] }\end{array}$ & $\begin{array}{l}\text { Name of } \\
\text { intervention }\end{array}$ & $\begin{array}{l}\text { Theoretical } \\
\text { framework }\end{array}$ & Subject & $\begin{array}{l}\text { Method and } \\
\text { materials }\end{array}$ & $\begin{array}{c}\text { Experime } \\
\text { ntal } \\
\text { period }\end{array}$ & $\begin{array}{l}\text { Sessions/ } \\
\text { time per } \\
\text { session } \\
\text { (minute) }\end{array}$ & $\begin{array}{c}\text { Follow-up } \\
\text { period }\end{array}$ & Measurement & Contents \\
\hline $\begin{array}{c}\text { Fawzia } \\
{[16]}\end{array}$ & $\begin{array}{l}\text { Develop- } \\
\text { mentally } \\
\text { supportive } \\
\text { positioning }\end{array}$ & $\cdot \mathrm{NA}$ & $\begin{array}{l}\text { Preterm } \\
\text { infants }\end{array}$ & $\begin{array}{l}\text { Develop- } \\
\text { mentally } \\
\text { supportive } \\
\text { positioning } \\
\text { practices }\end{array}$ & .7 days & $\begin{array}{l}\cdot \text { NA/ } 24 \\
\text { hours }\end{array}$ & $\cdot \mathrm{NA}$ & $\begin{array}{l}\cdot \text { Infant position } \\
\text { assessment tool } \\
\cdot \text { Preterm infant pain } \\
\text { profile }\end{array}$ & $\begin{array}{l}\text { Providing nest } \\
\text { during morning } \\
\text { routine nursing care } \\
\text { - Appling Snuggle-Up } \\
\text { similar to the uterus } \\
\text { - Appling Bendy } \\
\text { Bumper similar to } \\
\text { the abdominal wall } \\
\text { muscle }\end{array}$ \\
\hline $\begin{array}{l}\text { Griffiths } \\
\text { [7] }\end{array}$ & $\begin{array}{l}\text { - Individual- } \\
\text { ized } \\
\text { develop- } \\
\text { mental care }\end{array}$ & $\begin{array}{l}\text { Synactive } \\
\text { theory of } \\
\text { infant } \\
\text { develop- } \\
\text { ment }\end{array}$ & - Clinicians & $\cdot \mathrm{NA}$ & $\cdot \mathrm{NA}$ & $\cdot \mathrm{NA}$ & $\cdot \mathrm{NA}$ & $\cdot \mathrm{NA}$ & $\begin{array}{l}\cdot \text { Minimizing parent } \\
\text { and infant } \\
\text { separation } \\
\cdot \text { Maintaining } \\
\text { supportive sensory } \\
\text { environment } \\
\cdot \text { Protecting sleep } \\
\cdot \text { Feeding } \\
\text { - Providing } \\
\text { skin-to-skin care } \\
\cdot \text { Providing stress and } \\
\text { pain management } \\
\cdot \text { Fostering } \\
\text { interactions } \\
\text { - Applying } \\
\text { positioning } \\
\text { Supporting } \\
\text { continuity in } \\
\text { caregiving } \\
\text { Providing staff } \\
\text { education and } \\
\text { training }\end{array}$ \\
\hline $\begin{array}{l}\text { Luu } \\
\text { [29] }\end{array}$ & $\begin{array}{l}\cdot \text { Mieux } \\
\text { Agir au } \\
\text { Quotidien }\end{array}$ & $\cdot \mathrm{NA}$ & $\begin{array}{l}\text { - Parents of } \\
\text { preterm } \\
\text { infants }\end{array}$ & $\begin{array}{l}\text {-Workshop } \\
\text {-Web-based } \\
\text { platform } \\
\text { - Written } \\
\text { materials } \\
\text { - Videotaped } \\
\text { materials }\end{array}$ & $\cdot \mathrm{NR}$ & $\begin{array}{l}\cdot \text { Workshop: } \\
\text { 3/ } 1 \text { hour } \\
\text {-Web-based } \\
\text { module: } \\
4 / \text { NR }\end{array}$ & $\begin{array}{l}\cdot 4 \text {-and } \\
\text { 12-months, } \\
\text { CA }\end{array}$ & $\begin{array}{l}\text { - Parental cognitions } \\
\text { and conduct } \\
\text { toward the infant } \\
\text { scale } \\
\text { - Parenting stress } \\
\text { index-short form } \\
\text { - Bates' infant } \\
\text { characteristic } \\
\text { questionnaire } \\
\text { - Bayley scales of } \\
\text { infant and toddler } \\
\text { development } \\
\text { - Alberta infant } \\
\text { motor scales }\end{array}$ & $\begin{array}{l}\text { [Workshop] } \\
\text { - Infant behavioral } \\
\text { cues } \\
\cdot \text { Flexion positioning } \\
\cdot \text { Parent-infant } \\
\text { interactions } \\
\text { [Web-based module] } \\
\text { - Infant behavioral } \\
\text { cues } \\
\text { · Flexion positioning } \\
\cdot \text { Oral feeding support } \\
\text { (including } \\
\text { nonnutritive } \\
\text { sucking) } \\
\text { - Parent-infant } \\
\text { interactions }\end{array}$ \\
\hline $\begin{array}{l}\text { Moham- } \\
\text { med } \\
{[3]}\end{array}$ & $\begin{array}{l}\text { Preterm } \\
\text { neonates' } \\
\text { develop- } \\
\text { mental } \\
\text { supportive } \\
\text { care } \\
\text { program }\end{array}$ & $\begin{array}{l}\text { - Develop- } \\
\text { mental } \\
\text { clinical } \\
\text { care } \\
\text { guidelines }\end{array}$ & $\begin{array}{l}\cdot \text { Nurse in } \\
\text { NICU }\end{array}$ & $\begin{array}{l}\cdot \text { Lectures } \\
\cdot \text { Group } \\
\text { discussion } \\
\cdot \text { Simulation } \\
\cdot \text { Demonstration } \\
\cdot \text { Poster } \\
\cdot \text {-Video film } \\
\cdot \text { PowerPoint } \\
\text { presentation } \\
\cdot \text { Booklet }\end{array}$ & · 2 weeks & $\cdot 2 / 45$ & $\cdot 3$ months & $\begin{array}{l}\text { - Nurses' } \\
\text { performance } \\
\text { observational } \\
\text { checklist }\end{array}$ & $\begin{array}{l}\cdot \text { Definition of DSC } \\
\cdot \text { Benefits of applying } \\
\text { developmental } \\
\text { elements of DC } \\
\cdot \text { Reducing light and } \\
\text { noise } \\
\cdot \text { Positioning and } \\
\text { postural support } \\
\cdot \text { Non-nutritive } \\
\text { sucking } \\
\text {-Skin to skin care } \\
\text { using kangaroo care }\end{array}$ \\
\hline
\end{tabular}

CA, corrected age; DC, developmental care; DSC, developmentally supportive care; NA, not applicable; NICU, neonatal intensive care unit; NR, not reported; $[R]$, reference number. 
Table 4. Characteristics of Developmentally Supportive Care Interventions (Continued) $(N=6)$

\begin{tabular}{|c|c|c|c|c|c|c|c|c|c|}
\hline $\begin{array}{l}\text { First author } \\
\text { [R] }\end{array}$ & $\begin{array}{c}\text { Name of } \\
\text { intervention }\end{array}$ & $\begin{array}{l}\text { Theoretical } \\
\text { framework }\end{array}$ & Subject & $\begin{array}{l}\text { Method and } \\
\text { materials }\end{array}$ & $\begin{array}{l}\text { Experime } \\
\text { ntal } \\
\text { period }\end{array}$ & $\begin{array}{l}\text { Sessions/ } \\
\text { time per } \\
\text { session } \\
\text { (minute) }\end{array}$ & $\begin{array}{l}\text { Follow-up } \\
\text { period }\end{array}$ & Measurement & Contents \\
\hline $\begin{array}{l}\text { Moham- } \\
\text { med } \\
{[25]}\end{array}$ & $\begin{array}{l}\cdot \text { DSC } \\
\text { training } \\
\text { program }\end{array}$ & $\cdot \mathrm{NA}$ & $\begin{array}{l}\cdot \text { Neonatal } \\
\text { nurses }\end{array}$ & $\begin{array}{l}\text { Illustrated } \\
\text { Arabic booklet }\end{array}$ & · 2 weeks & $\begin{array}{l}\cdot 4 / \text { not } \\
\text { report }\end{array}$ & $\cdot$ NA & $\begin{array}{l}\text { - Interview } \\
\cdot \text { Neonatal } \\
\text { behavioral } \\
\text { assessment scale } \\
\text { - Observational } \\
\text { checklist }\end{array}$ & $\begin{array}{l}\text { - Characteristics of } \\
\text { neonates } \\
\text { - Behavioral cues of } \\
\text { neonates } \\
\text {-DC } \\
\text { · Nurses' role in DSC } \\
\text { - Positioning } \\
\text { - Lighting } \\
\text { - Noise control } \\
\text { - Nonnutritive } \\
\text { sucking } \\
\text { - Auditory, tactile, } \\
\text { olfactory, } \\
\text { gustatory, } \\
\text { vestibular } \\
\text { stimulation }\end{array}$ \\
\hline $\begin{array}{l}\text { Sathish } \\
\text { [4] }\end{array}$ & $\begin{array}{l}\cdot \text { DSC } \\
\text { program }\end{array}$ & $\begin{array}{l}\text { - Neonatal } \\
\text { integrative } \\
\text { develop- } \\
\text { mental } \\
\text { care model }\end{array}$ & $\begin{array}{l}\cdot \mathrm{NICU} \\
\text { nurses }\end{array}$ & $\cdot \mathrm{NR}$ & . 4 weeks & $\cdot 7 / 45$ & - 1 week & $\begin{array}{l}\cdot \text { DSC knowledge } \\
\cdot \text { DSC observational } \\
\text { checklist }\end{array}$ & $\begin{array}{l}\text { - Preterm infants and } \\
\text { fetal brain } \\
\text { development } \\
\cdot \text { Preterm behavioral } \\
\text { development } \\
\cdot \text { Minimizing stress } \\
\text { and pain } \\
\text { - Safeguarding sleep } \\
\cdot \text { Positioning and } \\
\text { handling } \\
\text { - Protecting skin } \\
\text { - Optimizing nutrition } \\
\cdot \text { Healing } \\
\text { environment in the } \\
\text { neonatal unit } \\
\text { - Partnering with } \\
\text { families }\end{array}$ \\
\hline
\end{tabular}

CA, corrected age; DC, developmental care; DSC, developmentally supportive care; NA, not applicable; NICU, neonatal intensive care unit; NR, not reported; [R], reference number.

routine prematurity care. Given that FCC is an important factor in developmentally supportive care, universal and practical guidelines for implementing FCC in a clinical setting need to be developed.

The purpose of the healing environment in developmentally supportive care is to minimize irritation and to create a safe and therapeutic space for premature infants in the ectopic environment $[1,6]$. Excessive stimulation such as pain, noise, light, and temperature in the NICU negatively affects the neuronal development of premature infants $[1,3]$. Therefore, it is necessary to maintain a safe environment in the NICU that supports the development of sight, hearing, taste, smell, and touch $[1,6]$. As part of the day-to-day practice of caring for preterm infants, NICU nurses should manage the environment to support their development [3]. Incorporating NICU environmental management into daily practice is meaningful because it is necessary for the development of premature infants.

Our review of the interventions of developmentally supportive care revealed that most of the studies were focused on training programs for NICU nurses. Zhang et al.[18] and Kim and Kim [30] reported that without NIDCAP or Wee Care,
NICU nurses lack competence because they learn developmentally supportive care based on the experience accumulated in a one-time training or practice rather than from systematic education. According to previous studies $[17,18]$, the lack of knowledge, negative attitudes toward developmentally supportive care, lack of educational experience, lack of experience in caring for prematurity, and resistance to change were barriers to providing developmentally supportive care. In other words, the quality of developmentally supportive care depends on the quality and competency of the NICU nursing staff [3]. A systematic training program to enhance the developmentally supportive care competency of NICU nurses is essential to improve the quality of care for preterm infants $[4,18,37]$. Therefore, it can be said that developmental support is currently at the stage of developing and evaluating NICU staff training programs, which must happen before the effects on quality improvement of care or developmental outcomes for premature infants can be examined.

To provide quality developmentally supportive care for premature infants, the NICU system and the personal traits of the care providers should be considered [9]. The NICU's work- 
ing conditions, financial support, manpower support, staff changes, and patient caseloads vary, depending on the health care system and the socio-cultural context of each country, and these points can act as barriers to developmentally supportive care $[17,18]$. Developmentally supportive care that is not supported by the institutional administration, increases the intensity of work for the NICU medical staff and negatively affects the work environment [10]. Therefore, it is necessary to construct the most appropriate and reasonable care program according to the conditions of each institution. This study confirmed that, under various conditions, many studies had actively developed interventions for developmentally supportive care and verified their effectiveness. We consider this to be a desirable research direction.

The limitation of this study is that data collection bias could have occurred because the reviewed papers were limited to English and Korean papers published since 2009. Another limitation is that literature search terms such as "high-risk infant", "delicate neonatal unit", and "neonatal special care unit" were not considered. However, this study was meaningful in that it reviewed related studies and sought future research directions at a time when the demand for supportive care for the development of premature infants is increasing worldwide. It is hoped that this study will serve as a cornerstone for actively developing interventions and attempting research on providing high-quality developmentally supportive care for premature infants in the NICU, where a structured developmentally supportive care program is not yet available.

\section{CONCLUSION}

This study presents results on the gap in research on developmentally supportive care for premature infants. Several studies have been conducted since the core measure of developmental support care for premature infants was announced in 2009 [6] and experimental studies have been attempted since 2014 [25]. More studies have been published on developmentally supportive care in the field of nursing in the last 5 years than in the past, and studies on developmental support have been gradually extended to various countries. The most important elements of developmentally supportive care were FCC and the NICU environmental management, which minimize the stimuli that hinder the development of premature infants. The primary developmentally supportive care interventions were training programs to promote the developmentally supportive care competency of NICU nurses. It is necessary to actively develop and evaluate interventions for comprehensive developmental support care that consider the various elements of developmentally supportive care for preterm infants. In the future, a meta-analysis study and system- atic literature review to identify the effectiveness of these interventions should be conducted.

Based on the results of this study, the researchers propose the following directions for future research regarding developmentally supportive care. Until now, research has mainly focused on NICU nurses, whereas future research needs to expand the research targets to include the NICU system, preterm babies, and their families. The interventions for developmentally supportive care identified in this study were mainly programs for training care providers. In the future, studies should be conducted to develop programs that provide direct interventions for premature infants and their families and to verify the effectiveness of those programs. Finally, when developing interventions for developmentally supportive care, it is recommended to develop an integrative intervention, either using the theoretical framework already reported or including the key elements identified in this study.

\section{ORCID}

Hanna Lee

Ji Hyeon Park

https://orcid.org/0000-0001-6084-262X

Haeryun Cho

https:// orcid.org/0000-0003-0484-2726

https:// orcid.org/0000-0001-7366-9774

\section{Authors' contribution}

Conceptualization: all authors; Data collection, Formal analysis: all authors; Writing-original draft, Writing-review and editing: all authors; Final approval of published version: all authors.

\section{Conflict of interest}

No existing or potential conflict of interest relevant to this article was reported.

\section{Funding}

This study was supported by a National Research Foundation of Korea (NRF) grant funded by the Korean government (No. NRF-2019R1I1A3A01060632).

\section{Data availability}

Please contact the corresponding author for data availability.

\section{Acknowledgements}

None. 


\section{REFERENCES}

1. Altimier L, Phillips R. The neonatal integrative developmental care model: advanced clinical application of the seven core measures for neuroprotective family-centered developmental care. Newborn and Infant Nursing Reviews. 2016;16(4):230-244.

https://doi.org/10.1053/j.nainr.2016.09.030

2. Chang YS. Future of neonatology in Korea; the way forward. Journal of Korean Medical Association. 2016;59(7):506-513.

https://doi.org/10.5124/jkma.2016.59.7.506

3. Mohammed RE, Khamis GM, Sabry YY. Effect of preterm neonates' developmental supportive care program on nurses' performance. IOSR Journal of Nursing and Health Science. 2018;7(4):33-45.

4. Sathish Y, Lewis LE, Noronha JA, Nayak BS, Pai MS, Altimier L. Promoting developmental supportive care in preterm infants and families in a level III neonatal intensive care unit (NICU) setting in India. Nurse Education in Practice. 2019;40:102612.

https://doi.org/10.1016/j.nepr.2019.08.006

5. Kim J, Shin H. Concept analysis of developmental care for preterm infants: hybrid model. Child Health Nursing Research. 2014;20(4): 350-358. https://doi.org/10.4094/chnr.2014.20.4.350

6. Coughlin M, Gibbins S, Hoath S. Core measures for developmentally supportive care in neonatal intensive care units: theory, precedence and practice. Journal of Advanced Nursing. 2009;65(10): 2239-2248. https://doi.org/10.1111/j.1365-2648.2009.05052.x

7. Griffiths N, Spence K, Loughran-Fowlds A, Westrup B. Individualised developmental care for babies and parents in the NICU: evidence-based best practice guideline recommendations. Early Human Development. 2019;139:104840. https://doi.org/10.1016/j.earlhumdev.2019.104840

8. Esser M, Dore S, Fitzgerald F, Kelly K, Kuller J, Ludwig S, et al. Applying developmentally Supportive principles to diapering in the NICU: what we know. Neonatal Network. 2018;37(3):149-154. https://doi.org/10.1891/0730-0832.37.3.149

9. NIDCAP Federation International Inc. NIDCAP [Internet]. Woburn, MA: NIDCAP Federation International Inc.; 2021 [cited 2021 April 8]. Available from: https://nidcap.org/

10. Mosqueda R, Castilla Y, Perapoch J, Lora D, López-Maestro M, Pallás C. Necessary resources and barriers perceived by professionals in the implementation of the NIDCAP. Early Human Development. 2013;89(9):649-653.

https://doi.org/10.1016/j.earlhumdev.2013.04.011

11. Altimier L, Kenner C, Damus K. The Wee Care Neuroprotective NICU Program (Wee Care): the effect of a comprehensive developmental care training program on seven neuroprotective core measures for family-centered developmental care of premature neonates. Newborn and Infant Nursing Reviews. 2015;15(1):6-16. https://doi.org/10.1053/j.nainr.2015.01.006

12. Legendre V, Burtner PA, Martinez KL, Crowe TK. The evolving practice of developmental care in the neonatal unit: a systematic review. Physical and Occupational Therapy in Pediatrics. 2011;31 (3):315-338. https://doi.org/10.3109/01942638.2011.556697

13. Burke S. Systematic review of developmental care interventions in the neonatal intensive care unit since 2006. Journal of Child Health Care. 2018;22(2):269-286. https://doi.org/10.1177/1367493517753085

14. Moody C, Callahan TJ, Aldrich H, Gance-Cleveland B, Sables-Baus S. Early initiation of newborn individualized developmental care and assessment program (NIDCAP) reduces length of stay: a quality improvement project. Journal of Pediatric Nursing. 2017;32:59-63. https://doi.org/10.1016/j.pedn.2016.11.001

15. Jannes C, Miedaner F, Langhammer K, Enke C, Göpel W, Kribs A, et al. Increased parental satisfaction by unrestricted visiting hours and developmentally supportive care in NICUs-results of a German multicenter study. The Journal of Maternal-Fetal and Neonatal Medicine. 2020;33(11):1874-1880.

https://doi.org/10.1080/14767058.2018.1532499

16. Fawzia EI, Rehab AE, Nehad AE. The effectiveness of developmentally supportive positioning on preterm infants' pain response at neonatal intensive care units. American Journal of Nursing Science. 2017;6(1):63-71. https://doi.org/10.11648/j.ajns.20170601.18

17. Austin B, Downing C, Hastings-Tolsma M. Experience of neonatal intensive care unit nurses in providing developmentally-supportive care: a qualitative study. Nursing and Health Sciences. 2019;21(3): 336-344. https://doi.org/10.1111/nhs.12603

18. Zhang X, Lee SY, Chen J, Liu H. Factors influencing implementation of developmental care among NICU nurses in China. Clinical Nursing Research. 2016;25(3):238-253.

https://doi.org/10.1177/1054773814547229

19. Hong H, Son HM. Factors influencing developmental care performance among neonatal intensive care units nurses. Child Health Nursing Research. 2020;26(2):131-139. https://doi.org/10.4094/chnr.2020.26.2.131

20. Charafeddine L, Masri S, Sharafeddin SF, Badr LK. Implementing NIDCAP training in a low-middle-income country: comparing nurses and physicians' attitudes. Early Human Development. 2020; 147:105092. https://doi.org/10.1016/j.earlhumdev.2020.105092

21. Seo HJ, Kim S. What is scoping review? Journal of the Health Technology Assessment. 2018;6(1):16-21.

https://doi.org/10.34161/johta.2018.6.1.003

22. Arksey H, O'Malley L. Scoping studies: towards a methodological framework. International Journal of Social Research Methodology. 2005;8(1):19-32. https://doi.org/10.1080/1364557032000119616

23. Tricco AC, Lillie E, Zarin W, O'Brien KK, Colquhoun H, Levac D, et al. PRISMA Extension for Scoping Reviews (PRISMA-ScR): checklist and explanation. Annals of Internal Medicine. 2018;169(7):467-473. https://doi.org/10.7326/m18-0850

24. Peters MD, Godfrey CM, Khalil H, Mclnerney P, Parker D, Soares CB. Guidance for conducting systematic scoping reviews. International Journal of Evidence-Based Healthcare. 2015;13(3):141-146. https://doi.org/10.1097/XEB.0000000000000050 
25. Mohammed SA, Bayoumi MH, Mahmoud FS. The effect of developmentally supportive care training program on nurses' performance and behavioral responses of newborn infants. Journal of Education and Practice. 2014;5(6):134-144.

26. Halder P, Bera D, Banerjee A. Developmentally supportive care in neonatal intensive care unit (NICU): a review. Indian Journal of Medical Research and Pharmaceutical Sciences. 2015;2(2):17-23.

27. Kaye S. Historical trends in neonatal nursing. Journal of Perinatal and Neonatal Nursing. 2016;30(3):273-276.

https://doi.org/10.1097/JPN.0000000000000200

28. Kim JS, Shin HS. Development of the developmental support competency scale for nurses caring for preterm infants. Journal of Korean Academy of Nursing. 2016;46(6):793-803. https://doi.org/10.4040/jkan.2016.46.6.793

29. Luu TM, Xie LF, Peckre P, Cote S, Karsenti T, Walker CD, et al. Web-based intervention to teach developmentally supportive care to parents of preterm infants: feasibility and acceptability study. JMIR Research Protocols. 2017;6(11):e236. https://doi.org/10.2196/resprot.8289

30. Kim MJ, Kim TI. Knowledge and performance of developmentally supportive positioning for premature infants among neonatal intensive care unit nurses. Child Health Nursing Research. 2018;24 (2):229-240. https://doi.org/10.4094/chnr.2018.24.2.229

31. Nejad MR, Eskandari Z, Heidarzadeh M, Afjeh A, Almasi-Hashiani A, Akrami F. Assessing infant-oriented care with developmental support approach in Iranian NICUs. Journal of Maternal-Fetal and Neonatal Medicine. 2018;31(14):1851-1855. https://doi.org/10.1080/14767058.2017.1330879

32. Khawash P, Banerjee M. Training of NICU staff in early developmental care of newborn-a perspective from India. EC Pediatrics. 2018;7(10):945-955

33. Baghlani R, Hosseini MB, Safaiyan A, Alizadeh M, ArshadiBostanabad M. Neonatal intensive care unit nurses' perceptions and knowledge of newborn individualized developmental care and assessment program: a multicenter study. Iranian Journal of Nursing and Midwifery Research. 2019;24(2):113-117. https://doi.org/10.4103/ijnmr.IJNMR_54_18

34. Choi E, Lee Y. A mother's experience of hospitalization of her newborn in the neonatal intensive care unit. Child Health Nursing Research. 2018;24(4):407-419. https://doi.org/10.4094/chnr.2018.24.4.407

35. Kang SR, Cho H. Research trends of follow-up care after neonatal intensive care unit graduation for children born preterm: a scoping review. International Journal of Environmental Research and Public Health. 2021;18(6):3268. https://doi.org/10.3390/ijerph18063268

36. Chung N, Kim Y, Park E, Yeo L, Hwang J. An integrative review of family interventions based on a philosophy of family-centered care in neonatal intensive care units. Perspectives in Nursing Science. 2019;16(1):35-44. https:// doi.org/10.16952/pns.2019.16.1.35

37. Valizadeh L, Asadollahi M, Mostafa Gharebaghi M, Gholami F. The congruence of nurses' performance with developmental care standards in neonatal intensive care units. Journal of Caring Sciences. 2013;2(1):61-71. https:// doi.org/10.5681/jcs.2013.008 


\section{Supplement 1. Database Search Strategies and Formulas}

\begin{tabular}{|c|c|c|c|}
\hline Database & Search & Queries & Item found \\
\hline \multirow[t]{5}{*}{ PubMed } & \#5 & $\begin{array}{l}(((\text { premature infant) OR (prematurity) OR (preterm infant)) AND ((( (developmentally } \\
\text { supportive care) OR (developmental support care) ) OR (integrative developmental care)) } \\
\text { AND (intensive care unit, neonatal [MeSH Terms])) AND infant, premature [MeSH Terms] } \\
\text { AND ( ( (NICU) OR (nurses)) OR (staff })))\end{array}$ & 231 \\
\hline & \#4 & (NICU) OR (nurses) OR (staff) & 252,060 \\
\hline & \#3 & intensive care unit, neonatal [MeSH Terms] OR infant, premature [MeSH Terms] & 36,537 \\
\hline & \#2 & $\begin{array}{l}\text { (((developmentally supportive care) OR (developmental support care)) OR (integrative } \\
\text { developmental care) })\end{array}$ & 10,535 \\
\hline & $\# 1$ & (premature infant) OR (prematurity) OR (preterm infant) & 105,715 \\
\hline \multirow[t]{7}{*}{ CINAHL } & S7 & S3 AND S6 & 10 \\
\hline & S6 & S4 AND S5 & 1,047 \\
\hline & S5 & (SU nurses* OR SU staff*) OR (TI nurses* OR TI staff*) OR (AB nurses* OR AB staff*) & 197,531 \\
\hline & S4 & (SU NICU) OR (TI NICU) OR (AB NICU) & 5,015 \\
\hline & S3 & S1 AND S2 & 38 \\
\hline & S2 & $\begin{array}{l}\text { (SU development* support* care OR SU integrative developmental care) OR (TI } \\
\text { development* support* care OR TI integrative developmental care) OR (AB development } \\
\text { support* care OR AB integrative developmental care) }\end{array}$ & 608 \\
\hline & S1 & $\begin{array}{l}\text { (SU premature infant OR SU prematurity OR SU preterm infant) OR } \\
\text { (TI premature infant OR TI prematurity OR TI preterm infant) OR } \\
\text { (AB premature infant OR AB prematurity OR AB preterm infant) }\end{array}$ & 21,268 \\
\hline \multirow{5}{*}{$\begin{array}{l}\text { Web of } \\
\text { Science }\end{array}$} & \#5 & \#4 AND \#3 & 38 \\
\hline & $\# 4$ & \#2 OR \#1 & 90,253 \\
\hline & $\# 3$ & $\mathrm{TI}=\left(\left(\right.\right.$ develop ${ }^{*}$ support $^{*}$ care $)$ OR (develop* support $^{*}$ care program $\left.)\right)$ & 338 \\
\hline & $\# 2$ & $\mathrm{TI}=((\mathrm{NICU}$ OR Neonatal intensive care unit) OR (nurses OR staff) $)$ & 79,224 \\
\hline & $\# 1$ & $\mathrm{TI}=(($ premature $\mathrm{OR}$ preterm $) \mathrm{AND}$ infant $)$ & 11,383 \\
\hline
\end{tabular}

$\mathrm{AB}$, abstract fields; CINAHL, Cumulative Index to Nursing and Allied Health Literature; MeSH, Medical Subject Headings; NICU, neonatal intensive care unit; $\mathrm{SU}$, subject heading; TI, terms in the title. 